\title{
Trend and Variability in Interannual Air Temperature Over South West Mau Forest, 1985 - 2015
}

\author{
Mathew Kiura kigomo ${ }^{1 *} \quad$ David Mwehia Mburu ${ }^{1} \quad$ James Mwangi Kinyanjui $^{2}$ \\ Aggrey Daniel Maina Thuo ${ }^{3}$ Charles Ndegwa Mundia ${ }^{4}$ \\ 1.Jomo Kenyatta University of Agriculture and Technology, P.O Box 62000-00200, City Square, Nairobi, Kenya \\ 2.Karatina University, P.O Box 1957-10101, Karatina, Kenya \\ 3.Kenyatta University, P.O Box 43844-00100, Nairobi, Kenya \\ 4. Dedan Kimathi University of Technology, Private Bag - 10143, Dedan Kimathi, Kenya
}

The research is sponsored by Jomo Kenyatta University of Agriculture and Technology and National Commission for Science, Technology and Innovation Kenya.

\section{Abstract}

Globally high altitude forest regions are considered to be more prone to rapid warming. These regions have also shown great seasonal and inter annual temperatures variability. In Kenya mean annual temperatures increased by $1.0^{\circ} \mathrm{C}$ since 1960 . Going by global trends it is plausible to argue that high altitude forest areas in Kenya might have shown great seasonal and inter annual temperatures variability over time. This study assessed interannual trend and variability as well as change point detection in average annual air temperature in South West Mau Forest, Kenya between 1985 and 2015. South West Mau Forest is an indigenous montane ecosystem with a tropical montane climate. Annual average air temperature over the South West Mau forest pointed towards climate warming of $0.0188^{\circ} \mathrm{C}$ per year (Kendall's tau $=0.3677, \mathrm{p}$ value $=0.0033$ ) but with low interannual variability $(\mathrm{CV}=0.11 \%)$. A shift in the annual average air temperature of $0.368^{\circ} \mathrm{C}$ at $\mathrm{p}=0.0051$ was detected between 1985 1998 and 1999- 2015. There was a weak positive anomaly in the annual average air temperature with a slope of 0.0192 and $\mathrm{R}^{2}=0.3074$. Overall the region experienced climate warming.

Keywords: Climate warming, Trend, Variability, Average temperature

DOI: $10.7176 / \mathrm{JNSR} / 11-16-04$

Publication date:August $31^{\text {st }} 2020$

\section{Introduction}

Global warming has attracted immense interest leading to numerous trend and variability analysis studies. Globally there has been an increasing trend in temperature since the late $19^{\text {th }}$ century. Between 1910-1945 temperatures increases of about $0.14^{\circ} \mathrm{C}$ per decade were detected. From 1976 temperature increases of about $0.17^{0} \mathrm{C}$ per decade were detected (Folland \& Karl 2001). In tropical Africa, temperature increases of about $0.15^{\circ} \mathrm{C}$ per decade were detected for the period between 1979 and 2010. Overall from 1906 to 2005 global mean temperature increased by approximately $0.74^{\circ} \mathrm{C}$ with half of the increase occurring in the last 25 years (IPCC 2007). The period between 2011 to 2015 was considered the hottest period on record and 2015 as the hottest since modern observation began in the late 1800s (Nouaceur \& Murarescu 2016; IPCC 2007). High altitude forest regions are considered to be more prone to rapid warming as shown by studies from Nepal, China and India (Shrestha et al. 1999; Liu \& Chen 2000; Jaswal et al. 2014). These regions have also shown great seasonal and inter annual temperatures variability (Beniston 2003). In Kenya mean annual temperatures increased by $1.0^{\circ} \mathrm{C}$ since 1960 (McSweeney et al. n.d). Going by global trends it is plausible to argue that high altitude forest areas in Kenya might have shown great seasonal and inter annual temperatures variability over time. The South West Mau Forest being part of indigenous montane ecosystem in Eastern Africa and having tropical montane climate may perhaps be experiencing significant interannual temperature variability. This study analysed trends and variability in annual average air temperature over South west Mau forest for the period between 1985 and 2015.

\section{Materials and Methods \\ 2.1 Study Area}

The South West Mau Forest, is part of the Mau forest complex of Kenya and it lies on longitudes $35^{\circ} .15^{\prime} 00^{\prime}$ ' $\mathrm{E}$ and $35^{\circ} .40^{\prime} 00^{\prime}$ 'E and latitudes $0^{0} .20^{\prime} 00^{\prime}$ 'S and $0^{\circ} .45^{\prime} 00^{\prime}$ 'S. It covers an area of approximately 84000 ha (Obati 2007). It is part of indigenous montane ecosystem in Eastern Africa. It falls under the tropical climate domain and tropical montane climate region described by FAO (2001). According to the agro-climatic map of Kenya (GOK 1980), about 80 percent of the Forest falls under the upper highlands with the remaining 20 percent being categorized as lower highlands (Figure 1). The upper highlands have mean annual temperature of between 12$16^{\circ} \mathrm{C}$ with the mean minimum temperatures ranging between $4-6^{\circ} \mathrm{C}$ and the mean maximum between $16-20^{\circ} \mathrm{C}$ and is classified as very cool to cool. The lower highlands have mean annual temperature of between $14-18^{\circ} \mathrm{C}$ with the mean minimum temperatures ranging between $8-12^{\circ} \mathrm{C}$ and the mean maximum between $20-24^{\circ} \mathrm{C}$ and is classified as fairly cool to cool temperature. In general, the average temperatures are in the range of $12-16^{\circ} \mathrm{C}$ but 
fall below $10^{\circ} \mathrm{C}$ during the cold season (Obati 2007) and the climate in the South West Mau Forest is classified as being humid (GOK 1980).

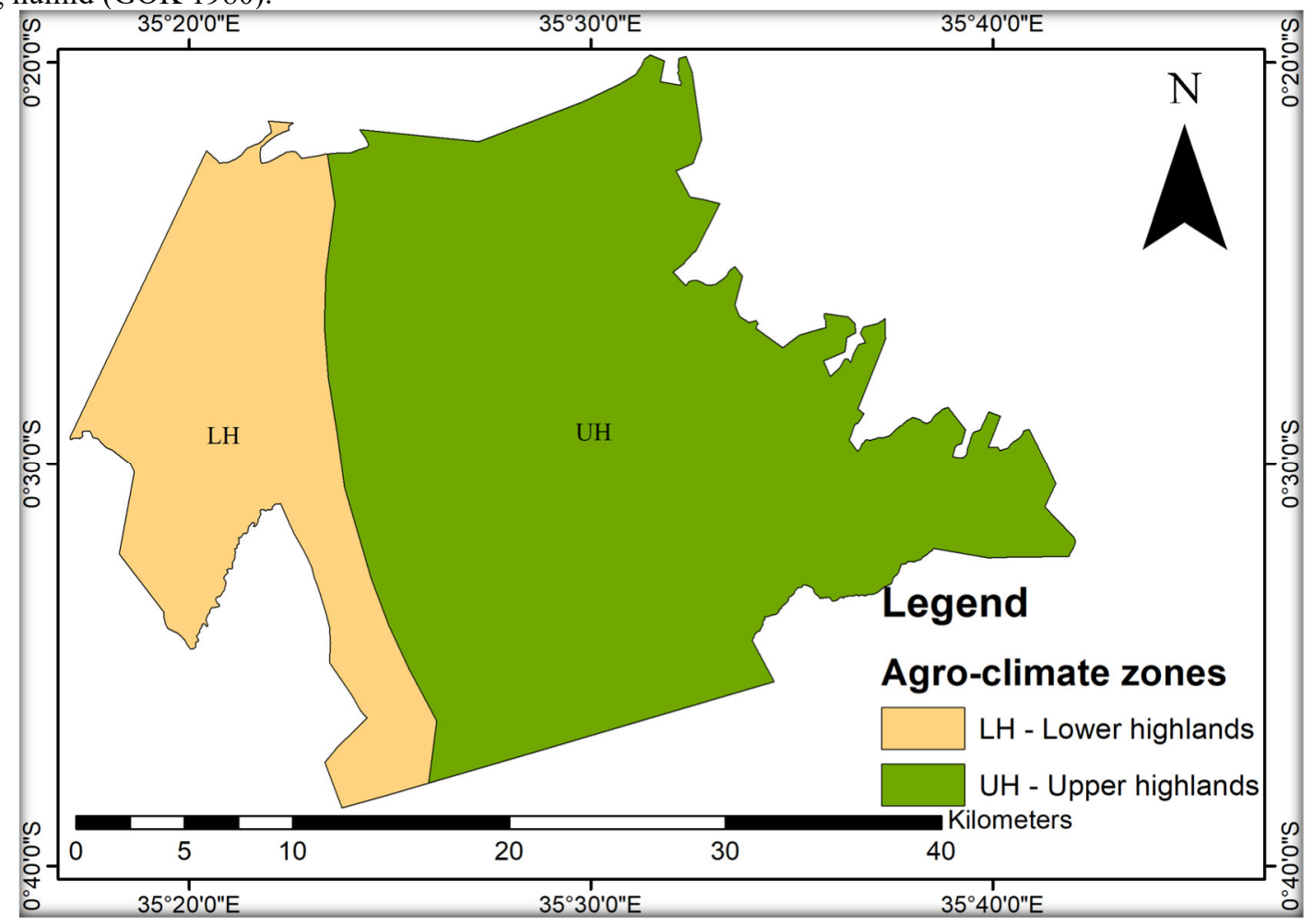

Figure 1: Agro-ecological zones of South West Mau Forest

\subsection{Data Collection}

Annual average air temperature (Table 1) for South West Mau was generated from averaged air temperature monthly data for the period between 1985 and 2015. The data was acquired from Giovanni, National Aeronautics and Space Administration Goddard Earth Science Data and Information Services Center (NASA GES DISC).

Table 1: Annual average air temperature for South West Mau (1985-2015)

\begin{tabular}{|r|l|r|r|r|r|}
\hline YEAR & $\begin{array}{l}\text { Annual average } \\
\text { air temperature } \\
\left({ }^{\mathbf{0}} \mathbf{C}\right)\end{array}$ & \multicolumn{1}{|l|}{ YEAR } & $\begin{array}{l}\text { Annual average air } \\
\text { temperature } \\
\left({ }^{\mathbf{0}} \mathbf{C}\right)\end{array}$ & \multicolumn{1}{l|}{$\begin{array}{l}\text { YEAR } \\
\text { temperature } \\
\left({ }^{\mathbf{0}} \mathbf{C}\right)\end{array}$} \\
\hline $\mathbf{1 9 8 5}$ & 15.4762 & $\mathbf{1 9 9 5}$ & 15.9786 & $\mathbf{2 0 0 5}$ & 16.6826 \\
\hline $\mathbf{1 9 8 6}$ & 15.7695 & $\mathbf{1 9 9 6}$ & 15.9068 & $\mathbf{2 0 0 6}$ & 16.3523 \\
\hline $\mathbf{1 9 8 7}$ & 16.0201 & $\mathbf{1 9 9 7}$ & 16.1472 & $\mathbf{2 0 0 7}$ & 15.9410 \\
\hline $\mathbf{1 9 8 8}$ & 15.9009 & $\mathbf{1 9 9 8}$ & 15.9006 & $\mathbf{2 0 0 8}$ & 16.0881 \\
\hline $\mathbf{1 9 8 9}$ & 15.3989 & $\mathbf{1 9 9 9}$ & 16.1010 & $\mathbf{2 0 0 9}$ & 16.5965 \\
\hline $\mathbf{1 9 9 0}$ & 15.5457 & $\mathbf{2 0 0 0}$ & 16.5212 & $\mathbf{2 0 1 0}$ & 15.8521 \\
\hline $\mathbf{1 9 9 1}$ & 16.1317 & $\mathbf{2 0 0 1}$ & 15.9964 & $\mathbf{2 0 1 1}$ & 16.1075 \\
\hline $\mathbf{1 9 9 2}$ & 16.0466 & $\mathbf{2 0 0 2}$ & 16.3765 & $\mathbf{2 0 1 2}$ & 15.9282 \\
\hline $\mathbf{1 9 9 3}$ & 15.8773 & $\mathbf{2 0 0 3}$ & 16.2448 & $\mathbf{2 0 1 3}$ & 15.9180 \\
\hline $\mathbf{1 9 9 4}$ & 16.1001 & $\mathbf{2 0 0 4}$ & 16.4333 & $\mathbf{2 0 1 4}$ & 16.3115 \\
\hline & & & & $\mathbf{2 0 1 5}$ & 16.6069 \\
\hline
\end{tabular}

Table 2 below illustrates the features of the average air temperature data. FLDAS stands for Famine Early Warning Systems Network (FEWS NET) Land Data Assimilation System. This is a drought monitoring systems which rely on satellite remote sensing and land surface models to produce multi-model and multi-forcing estimates of hydro-climate states and fluxes over semi-arid regions of Africa (McNally et al. 2017). 
Table 2: Features of average air temperature data for used for the study

\begin{tabular}{ll}
\hline Variable & Air temperature (FLDAS_NOAH01_C_EA_M v001) \\
\hline Units & Degree Celsius \\
Source & FLDAS model \\
Temporal resolution & Monthly \\
Land region & Sub-Saharan Africa \\
Spatial resolution & $0.1^{0}$ \\
Observations & Satellite and land surface models \\
Begin data & $1985-01-01$ \\
End date & $2015-12-31$ \\
\hline
\end{tabular}

\subsection{Data Analysis}

Annual average air temperature was all analysed for trend, change point detection and variability. Trend was analysed using Mann Kendall test which is a non parametric test that is used to assess whether data points in a data series have a significant monotonic upward or downward trend. A positive value indicates upward or increasing trend, while a negative value indicates downward or decreasing trend in the time series. Mann Kendall showed whether the temperature was tending towards warming or cooling and the significance of the trend. Change point was performed using Petit test to establish whether there were significant break point in average annual air temperatures in the time series (Asfaw et al. 2018; Ukhurebor \& Abiodun 2018; Jaiswal \& Tiwari 2015; Pohlert 2018).Variability analysis was performed using anomaly analysis and coefficient of variation. Anomaly (A) testing was computed by subtracting the time series mean $\left(\mu_{30}\right)$, from yearly mean $\left(X_{i}\right)$ (equation 1 ). It returns values that are either higher than the time series mean designated by a positive value or values that are lower than the time series mean designated by a negative value (Ukhurebor \& Abiodun 2018). Anomaly analysis enabled the detection of average annual air temperatures that were warmer than the climatological normal designated by positive values and cooler than the climatological normal designated by negative values.

$\boldsymbol{A}=\boldsymbol{X}_{\boldsymbol{i}}-\mu_{30}$

Equation 1

Coefficient of variability for average annual air temperature from 1985 to 2015 was computed by comparing the standard deviation $(\boldsymbol{\delta})$ in the time series relative to the mean $(\mu)$ as shown in equation 2 (Asfaw et al. 2018; Ukhurebor \& Abiodun 2018).

$\boldsymbol{C V}=\frac{\boldsymbol{\delta}}{\mu} \times \mathbf{1 0 0}$ Equation 2

The temperature data was converted from degree Celsius to Kelvin since coefficient of variability is meaningful only for data measured on a ratio scale. Temperature data in degree Celsius is considered as data with interval scale and as such it has no real zero or meaningful zero (Abdi 2010). Coefficient of variability (CV) values below 0.30 percent indicated low variability, values between 0.30 percent and 0.42 percent indicated moderate or average variability, value between 0.42 percent and 0.48 percent indicated high variability, while values above 0.48 percent indicated very high variability. This classification was computed using the mean and standard deviation of coefficient of variability for annual average air temperature in South West Mau forest between 1985 and 2015 and based on the criteria proposed by Garcia in 1989 (Ferreira et al. 2018; Couto et al. 2013; Vaz et al. 2017). The criteria are presented in table 3 . The mean and standard deviation of coefficient of variability for average annual air temperature in South West Mau forest between 1985 and 2015 were 0.0036 and 0.0006 respectively.

\section{Table 3: Criteria of classification of coefficient of variation}

\begin{tabular}{ll}
\hline Coefficient of variation classification criteria & Classification \\
\hline $\mathrm{CV} \leq(\mathrm{A}-1 \mathrm{~B})$ & Low \\
$(\mathrm{A}-1 \mathrm{~B})<\mathrm{CV} \leq(\mathrm{A}+1 \mathrm{~B})$ & Moderate or average \\
$(\mathrm{A}+1 \mathrm{~B})<\mathrm{CV} \leq(\mathrm{A}+2 \mathrm{~B})$ & High \\
$\mathrm{CV}>(\mathrm{A}+2 \mathrm{~B})$ & Very high \\
\hline
\end{tabular}

Where $\mathrm{A}$ and $\mathrm{B}$ are the mean and standard deviation of the coefficient of variation respectively

\section{Results and Discussions}

The climatological normal (mean annual average air temperature between 1985 and 2015) in the SWM forest was $16.0728^{\circ} \mathrm{C}$ with $0.3144^{\circ} \mathrm{C}$ standard deviation. The maximum annual average air temperature was $16.6826^{\circ} \mathrm{C}$ experienced in 2005 while the minimum annual average air temperature was $15.3989^{\circ} \mathrm{C}$ experienced in 1989 . Inter annual time series analysis (Figure 2) using Mann-Kendall test at 5 percent confidence interval revealed a statistically significant increasing trend in the annual average air temperature in the South West Mau forest for the period between 1985 and 2015, with a Kendall's tau of 0.3677 , Sen's slope of 0.0188 , p value (two tailed) of 0.0033. The results signify that there is trend towards climatic warming in the South West Mau forest between 1985 and 2015 . 


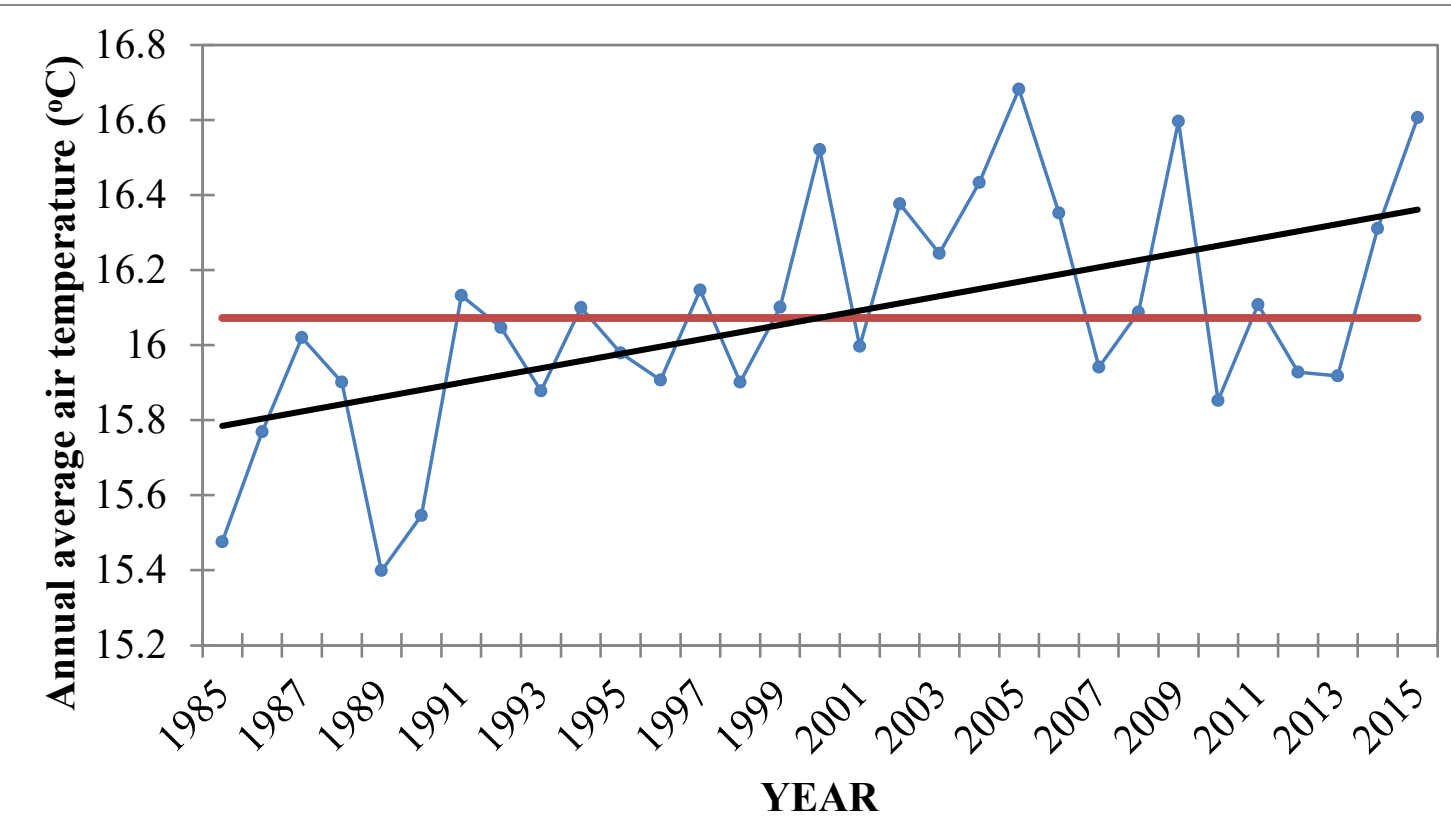

$\rightarrow$ Annual average air temperature

Climatological mean

一线性 (Annual average air temperature)

Figure 2: Inter annual time series of average air temperature in SWM (1985- 2015)

Petit test of homogeneity revealed that there was a change point of $0.368^{\circ} \mathrm{C}$ in the interannual average air temperature in 1998 with a $\mathrm{p}$ value (two tail) of 0.0051 at 99 percent confidence level. This implied that the observed increase in annual average air temperature occurred in two distinct periods, the first beginning in the year 1985 and ending in 1998 and the second being from1999 to 2015 (Figure 3). The means in annual average air temperature of the two periods were $15.871^{\circ} \mathrm{C}$ and $16.239^{\circ} \mathrm{C}$ respectively. The results from the Petit test supported the indication that there was significant climate warming over the South West Mau Forest for the period between 1985 and 2015.

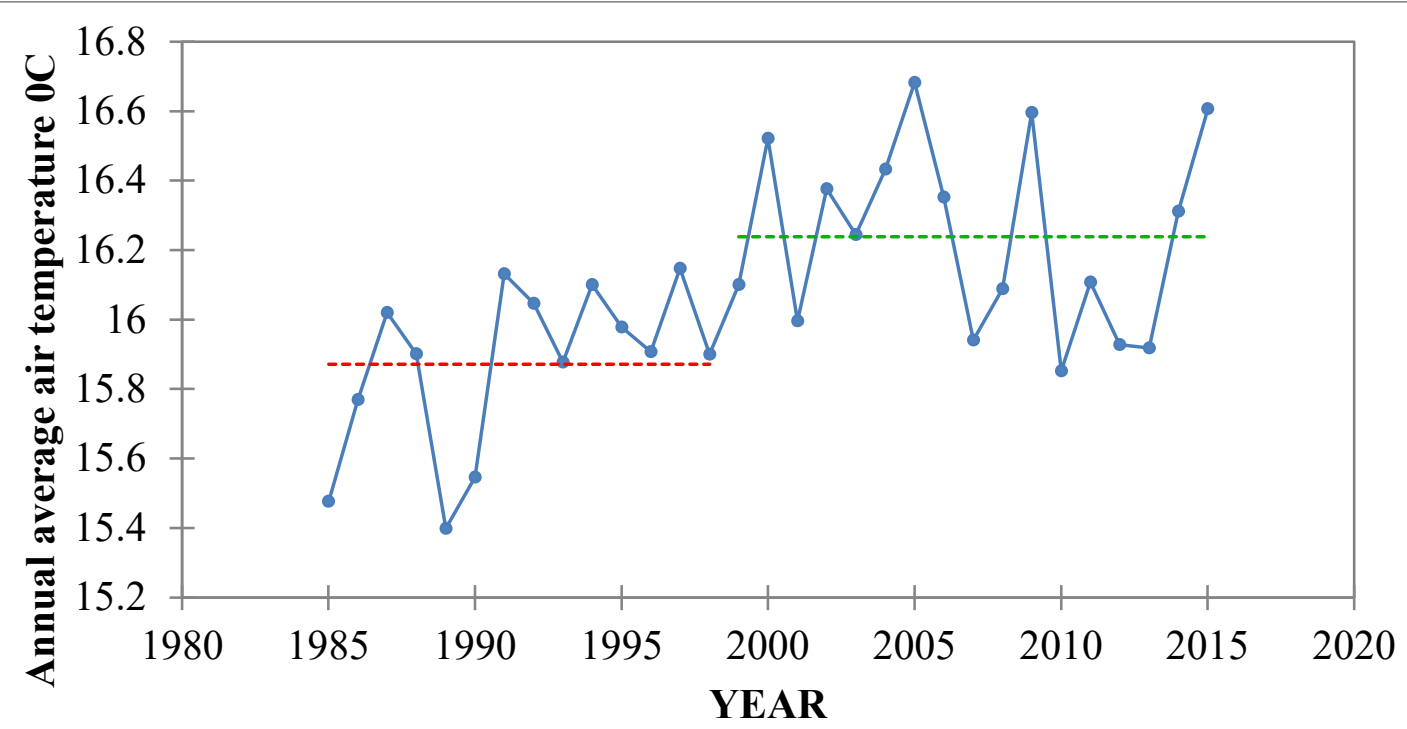

$$
\begin{aligned}
& \longrightarrow \text { Annual average air temperature ------- } \mathrm{mu} 1=15.871 \\
& ------\mathrm{mu} 2=16.239
\end{aligned}
$$

Figure 3: Shift in inter annual average air temperature in SWM (1985-2015) 
Inter annual average air temperature anomalies in the South West Mau between 1985 and 2015 (Figure 4) had a gradient of 0.0192 implying an overall positive anomaly which pointed towards climatic warming. The results showed that 48 percent of the years had an annual average air temperature with a positive anomaly and 52 percent had an annual average air temperature with a negative anomaly. Although there were more cooler years than warm years, the warm years had more extreme anomalies resulting in the trend towards warming. Extreme positive anomalies in annual average air temperatures were prominent for the years 2000, 2005, 2009 and 2015 while the extreme negative anomalies in annual average air temperatures were prominent for the years 1985, 1989 and 1990. Further scrutiny of the results revealed that annual average air temperatures between 1985 and 1998 with the exception of 1991, 1994 and 1997 had a negative anomaly an indication of cooling with reference to the climatological normal. Annual average air temperatures between 1999 and 2015 with the exception of 2001, 2007, 2010, 2012, and 2013 had a positive anomaly and indication of warming with reference to the climatological normal. The observation made is that cooling occurred early in the time series while warming occurred late in the time series.

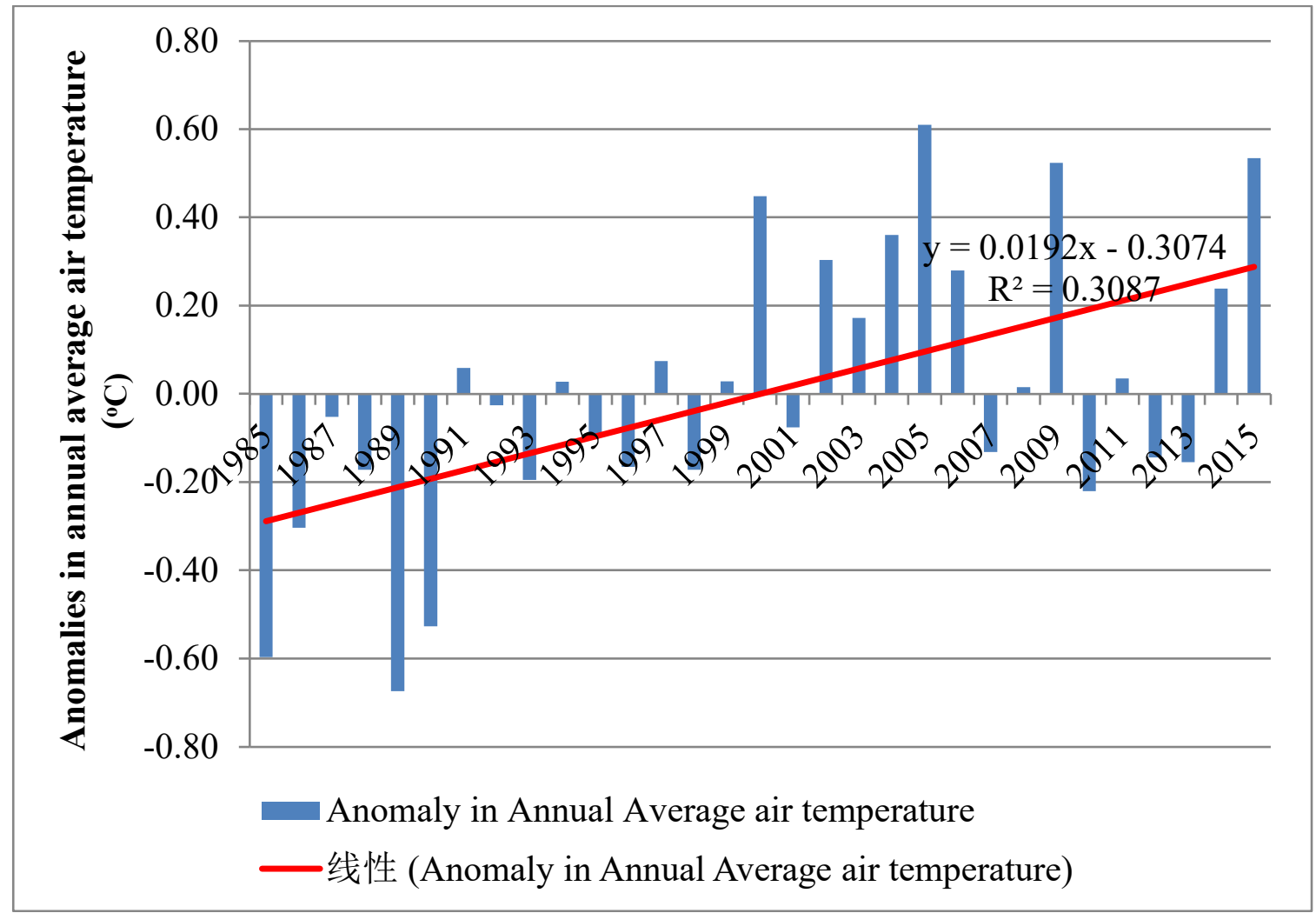

Figure 4: Anomalies in annual average air temperature for SWM (1985-2015)

These results are in agreement with those from Petit test that there is a shift from cool conditions to warmers conditions. The coefficient of variability was 0.11 percent implying a low variability in the annual average air temperature over the South West Mau forest between 1985 and 2015.Overall all the results pointed towards climatic warming in the South West Mau between 1985 and 2015 with low year to year variability

\section{Conclusions}

Annual average air temperature over the South West Mau forest pointed towards a significant climate warming of $0.0188^{\circ} \mathrm{C}$ per year between 1985 and 2015 . There was also a remarkable shift in the annual average air temperature of $0.368^{\circ} \mathrm{C}$ between the periods 1985 to 1998 and 999 to 2015 . Along with the climate warming more frequent warm extremes and less cool extremes relative to the normal annual average air temperature events were experienced over South West Mau forest between 1985and 2015.

\section{References}

Abdi, H., 2010. Coefficient of Variation. In: Encyclopedia of Research Design. Thousand Oaks, CA: Sage.

Asfaw, A., Simane, B., Hassen, A. \& Bantider, A., 2018. Variability and time series analysis of rainfall and temperatue in northcentral Ethiopia: A case study in Woleka sub-basin. Weather and Climate Extremes, Issue 19 , pp. 29-41.

Beniston, M., 2003. Climatic change in mountain regions: a review of possible impacts. Climate change, Volume 59, pp. 5-31. 
Couto, M., Peternelli, L. \& Barbosa, M., 2013. Classification of the coefficients of variation for sugarcane crops. Ciência Rural, Santa Maria, 43(6), pp. 957-961.

Ferreira, A. et al., 2018. Methods for classifying coefficient of variation in experimetnation with poultrys. Comunicata Scientiae, 9(4), pp. 565-574.

Folland, C. K. \& Karl, T. R., 2001. Observed climate variability and change. In: Climate change. Cambridge : Cambridge University Press, pp. 99 - 181.

GOK. 1980. Agro-ecological zones of Kenya. Nairobi: GOK.

IPCC. 2007. Climate Change 2007: The Physical Science Basis. Contribution of Working Group I to the 4th Assessment Report of the Intergovernmental Panel on Climate Change [Solomon, S., D. Qin, M. Manning, Z. Chen, M. Marquis, K. Averyt, M. Tignor and H. Miller (eds)]. Cambridge, United Kingdom and New York, NY, USA: Cambridge University Press.

Jaiswal, R. K. \& Tiwari, H., 2015. Statistical Analysis for Change Detection and Trend Assessment in Climatological Parameters. Environ, Volume 2, pp. 729-749.

Jaswal, A. K., Kumar, N. \& Khare, P., 2014. Climate variability in Dharamsala - a hill station in Western Himalayas. J. Ind. Geophys. Union, 18(3), pp. 336-355.

Liu, X. \& Chen, B., 2000. Climate warming in the Tibetan Plateau during recent decades. International Journal of climate, Volume 2, pp. 1729-1742.

McNally, A. et al., 2017. Land data assimilation system for sub-Saharan Africa food and water security applications. Scientific data.

McSweeney, S., New, M. \& Lizcano, G., n.d. UNDP climate change country profile, Kenya, s.1.: UNDP.

Nouaceur, Z. \& Murarescu, O., 2016. Rainfall variability and trend analysis of annual rainfall in North Africa. International Journal of Atmospheric Sciences, pp. 1-12.

Obati, G. O., 2007. An investigation of forest ecosystem health in relation to anthropogenic disturbance in the SouthWestern Mau Forest Reserve, Kenya, s.1.: University of Bremen.

Pohlert, T., 2018. Non-parametric trend tests and change point detection, s.1.: s.n.

Shrestha, A. B., Wake, C. P., Mayewski, P. A. \& Dibb, J. E., 1999. Maximum temperature and trends in the Himalaya and its vicinity: An analysis based on temperature records from Nepal from period 1971-94. Journal of Climate, Volume 2, pp. 2775-2787.

Ukhurebor, K. \& Abiodun, I., 2018. Variation in annual rainfall data of forty years (1978-2017) for South-south, Nigeria. JASEM, 22(4), pp. 511-518.

Vaz, M., Pacheco, P., Seidel, E. \& Ansuj, A., 2017. Classification of the coefficient of variation to variables in beef cattle experiments. Ciência Rural, Santa Maria, 47(11).

WWF, 2001. East African montane forests, s.1.: s.n. 